\title{
AN ANALYSIS OF SWEAR WORDS IN "ONCE UPON A TIME... IN HOLLYWOOD” FILM
}

\author{
Peggy Andriani Kakisina, ${ }^{1, *}$, Isti Purwaningtyas ${ }^{2}$ \\ ${ }^{1}$ Department of Languages and Literature, Faculty of Cultural Studies, Universitas Brawijaya, Malang 65145, \\ Indonesia \\ ${ }^{2}$ Department of Languages and Literature, Faculty of Cultural Studies, Universitas Brawijaya, Malang 65145, \\ Indonesia
}

\section{A R TICLE INFO}

Keywords:

Once Upon a Time... in

Hollywood

Swear Word

Semantic referent

Swearing motive

Article History:

Received: 30/05/2020

Accepted: 16/11/2020

Available Online:

30/11/2020

\begin{abstract}
A B S T R A C T
Swear words are one of the linguistic choices which show cultural aspects. Found in both oral and written forms. Swear words represent emotions and convey powerful messages. Some people utter swear words because of specific reasons, and they occasionally ignore their literal meaning. The phenomenon of swearing also happens in films. Based on the film Once Upon a Time... in Hollywood, this qualitative research addressed the semantic referents of swear words and the motives of swearing. By employing content analysis, the results show that (a) 59 swear words are classified into nine semantic referents, consisting of offensive slang (17\%) as the main referent, followed by profane or blasphemous (15\%), psychological-physical-social deviations (15\%), scatological and disgusting objects (15\%), sexual references (12\%), substandard vulgar terms (10\%), ethnic-racial-gender slurs (7\%), animal names (5\%), and ancestral allusions (4\%) and (b) swearing are caused by three motives, namely psychological, social, and linguistic. The study concludes that the film contains severe and various swear words, and particular situations can lead the characters to swear. General readers are hoped to be more considerate in expressing themselves and be wiser in determining their word choices.
\end{abstract}

2442-305X / (C) 2020 The Authors, this is open access article under the (CC-BY-NC) license (https://creativecommons.org/licenses/by-nc/4.0/), DOI: 10.19105/ojbs.v14i2.3394

\footnotetext{
* Corresponding Author:

Email address: peggykakisina@gmail.com (P. A. Kakisina)
}

\section{A. Introduction}

As the initial communicative device, language holds an essential role in connecting people. English as the global language serves as the lingua franca that unites people across the world. Like any other language, English contains a power that can impact the speaker and the hearer. This kind of influence can be delivered in the form of swear words.

Swearing has always been considered as an inappropriate act. Regardless of the offensiveness, swear words are used in everyday lives, merely as a means of expressing people's emotions. However, the meaning of swear 
words and the reasons for swearing are barely acknowledged by the speakers themselves. Andersson and Trudgill define swear word as a type of language which refers to taboo things, illustrates powerful feelings, and should be interpreted imprecisely. ${ }^{1}$ However, Karjalainen argues that not all taboo words are classified into swear words. ${ }^{2}$

As one of the activities that some people might find taboo and offensive, swearing is marked by the connection of powerful attitudes and emotions, the social context between the addressers and the addressees, as well as the formality and the nature of the circumstances. $^{3}$ Jay suggests that a swearing style depends on the personal knowledge formed by individual experiences, psychological construction, and the culture whereby the person is raised. ${ }^{4}$ This implies that swearing behavior is a product of social and cultural contexts during the process of psychological development.

Some people may avoid uttering swear words, yet others tend to insert them due to various reasons while

\footnotetext{
1 L. Andersson and P. Trudgill, Bad Language (Oxford: Blackwell, 1990), 53.

2 Markus Karjalainen, "Where Have All the Swearwords Gone? An Analysis of the Loss of Swearwords in Two Swedish Translations of J. D. Salinger's Catcher in the Rye," Pro Gradu Thesis Faculty of Arts Department of English University of Helsinki (University of Helsinki, 2002), 18.

${ }^{3}$ Ad J. J. M. Vingerhoets, Lauren M. Bylsma, and Cornelis de Vlam, "Swearing: A Biopsychosocial Perspective," Psychological Topics 22, no. 2 (2013): 287-304.

${ }^{4}$ Timothy Jay, Why We Curse: A Neuro-PsychoSocial Theory of Speech (Amsterdam: John Benjamins, 1999), 20.
}

communicating. Informal situations also tend to be the most appropriate occasion whereby people may express themselves through swear words. ${ }^{5}$ Because of that, the status of swearing as a rude and offensive act decreases. It also gradually loses the ability to create shock value for becoming more accustomed around societies. ${ }^{6}$ Thereby, swearing turns into a culture, a part of a social life now.

The use of swear words in social life continues to evolve and eventually shift through generations. The persistence and the offensiveness are the outcomes of the addressees' viewpoint regarding the topics instead of the words alone. The government also tolerates the use of vulgar language by allowing ideas, such as verbal art, containing words that may be considered offensive by some people. ${ }^{7}$

Kristiano and Ardi describe that the literal meaning of swear words is generally neglected since they do not represent what is intended to be referred to as swearing. ${ }^{8}$ This prompts the use of swear words connotatively. The connotative meaning of swear words is

\footnotetext{
${ }^{5}$ Yehuda Baruch et al., "Swearing at Work: The Mixed Outcomes of Profanity," Journal of Managerial Psychology 32, no. 2 (2017): 149-62, https://doi.org/10.1108/JMP-04-2016-0102.

6 Karyn Stapleton, "Swearing," in Interpersonal Pragmatics (New York: De Gruyter Mouton, 2010), 289-305.

7 Edwin L. Battistella, Bad Language: Are Some Words Better than Others? (New York: Oxford University Press, 2007), 76. https://doi.org/10.1093/acprof:oso/9780195172485. 001.0001.

8 Johan Tobias Kristiano and Priyatno Ardi, "Swear Words in Bad Boys II: A Semantic Analysis," Journal: A Journal on Language and Language Teaching 21, no. 2 (2018): 191-98, https://doi.org/10.24071/ltt.2018.210208.
} 
related to the personal association that shows a specific attitude to a particular entity or circumstance.

The literal meaning, usually coded as the denotative meaning, is carried in a referent. Kreidler states that referent is the extralinguistic object referred by a word. ${ }^{9}$ Referent is not the same as reference. He defines reference as the relational concept between a language form and some physical entity, which is the referent of that sign. In other words, reference and referent illustrate the successful way of the speakers and the hearers in using language expressions since they both have the same common knowledge about a certain situation of language use.

Jay identifies types of semantic referents of swear words as sexual references (expressed through sexual terms related to sexual acts, sexual anatomies, and sexual deviations); profane or blasphemous (expressed through religious denotations); scatological and disgusting objects (expressed through excretion organs and processes as well as body products); animal names; ethnic-racial-gender slurs (expressed through hate speech, discrimination, and pride of own culture); psychological - physical - social deviations (expressed through psychological states, physical appearances, and against-norm); ancestral allusions (expressed through family members and ancestors); substandard vulgar terms (expressed through offensive phrases that are below

9 Charles W Kreidler, Introducing English Semantics (London: Routledge, 1998), 131. https://doi.org/10.4324/9780203265574. the satisfactory standard of language), and; offensive slang (expressed through slang which contains insult). ${ }^{10}$ Horan also argues that swear words are usually structured out of animals, sex, bodily excretions, and disease. ${ }^{11}$ In agreement with Jay, Trudgill asserts that taboo words involve terms linked to sex, excretion, religion, animals, and female relation. ${ }^{12}$

Despite their inappropriateness, swear words offer various functions to the addressers. They imply verbal aggression, represent group identity, reflect the emotions, emphasize, and serve as grammatical categories. ${ }^{13}$ Swearing does not merely celebrate the verbal aggression but also a means to cope with anger which will escalate into positive affective valence and lower physical activation. $^{14}$

\footnotetext{
10 Timothy Jay, "The Utility and Ubiquity of Taboo Words," Perspectives on Psychological Science 4, no. 2 (2009): $153-61$, https://doi.org/10.1111/j.1745-6924.2009.01115.x.

11 Geraldine Horan, "You Taught Me Language; and My Profit on't/ls, I Know How to Curse': Cursing and Swearing in Foreign Language Learning," Language and Intercultural Communication 13, no. 3 (2013): 283-97, https://doi.org/10.1080/14708477.2013.804533.

12 Peter Trudgill, Sociolinguistics: An Introduction to Language and Society, 4th ed. (London: Penguin Books, 2000), 18. https://doi.org/10.2307/326846.

${ }^{13}$ Eric Holgate et al., "Why Swear? Analyzing and Inferring the Intentions of Vulgar Expressions," in Proceedings of the 2018 Conference on Empirical Methods in Natural Language Processing, EMNLP 2018 (Brussels, 2018), 4405-14, https://doi.org/10.18653/v1/d18-1471.

${ }^{14}$ Simona A. Popuşoi, Grigore M. Havârneanu, and Corneliu E. Havârneanu, "Get the F\#*k out of My Way!' Exploring the Cathartic Effect of Swear Words in Coping with Driving Anger," Transportation Research Part F: Traffic Psychology and Behaviour 56 (2018): 215-26, https://doi.org/10.1016/j.trf.2018.04.013.
} 
Vingerhoets, Bylsma, and de Vlam claim that swearing provides interpersonal consequences, which are parted into intra-individual functions and interindividual functions. Positive intraindividual roles create stress relief, aggressive reduction, pain tolerance, and confidence, while the negative effects are realized through disapproval and negative judgment. Positive inter-individual aim to signal the emotions, discontinue unwanted activities, increase perceived credibility, enhance persuasiveness, serve as group binding, identity marker, and humor elicitation. Feeling socially isolated and rejected, fear, hostility, indignity, and loss of status are the disadvantages of inter-individual functions. ${ }^{15}$

Every swear word signifies power. When people do not expect to produce swear words, the use of these terms may create a shock to the addressee, but it makes the addresser easier to receive the goal of uttering them. Andersson (as cited in Karjalainen) ${ }^{16}$ proposes three types of reasons for swearing, that are grouped into psychological motives (PM), social motives (SM), and linguistic motives (LM).

In psychological motives, swearing is assumed as a way of expressing feelings and reducing stress. The emotional feelings included in this category are non-emphatic feelings, anger, frustration, surprise, sorrow, and joy. Stephens and Zile also assert that the

\footnotetext{
${ }^{15}$ Vingerhoets, Bylsma, and de Vlam, "Swearing: A Biopsychosocial Perspective," 296.

${ }^{16}$ Karjalainen, "Where Have All the Swearwords Gone? An Analysis of the Loss of Swearwords in Two Swedish Translations of J. D. Salinger's Catcher in the Rye," 2002, 24.
}

swearing fluency can be induced by increasing emotional arousal. ${ }^{17}$ Holmes reveals that each swear word forms different functions depending on the social context. $^{18}$ Therefore, in terms of social motives, swearing functions to amuse, insult, and shock the addressee. It can also illustrate intimacy or friendship, strengthen group identity, along with social distance and solidarity. Social distress, such as being rejected, excluded, or spurned, may trigger the speaker to respond by swearing and showing aggression. ${ }^{19}$ Through linguistic motives, swearing is not employed directly to insult or express emotions. They also appear as pure motives on linguistic subjects. Moreover, they emphasize what the speakers attempt to state and indicate their daily conversational style.

Swear words are the relatively neglected research areas, and there are few studies regarding this topic in films. With the exception of Cahyani and Setiawan $^{20}$ who analyzed the form and

17 Richard Stephens and Amy Zile, "Does Emotional Arousal Influence Swearing Fluency?," Journal of Psycholinguistic Research 46, no. 4 (2017): 983-95, https://doi.org/10.1007/s10936016-9473-8.

18 Janet Holmes, An Introduction to Sociolinguistics, 4th ed. (New York: Routledge, 2013), 283. https://doi.org/10.1525/jlin.2003.13.2.252.

19 Michael C. Philipp and Laura Lombardo, "Hurt Feelings and Four Letter Words: Swearing Alleviates the Pain of Social Distress," European Journal of Social Psychology 47, no. 4 (2017): 51723, https://doi.org/10.1002/ejsp.2264.

20 Putri Dwi Cahyani and Teguh Setiawan, "Swearing Words on Yowis Ben Movie by Fajar Nugros and Bayu Skak," in International Conference on Interdisciplinary Language, Literature and Education (ICILLE 2018) (Paris: Atlantis Press, 2019), 282-87, https://doi.org/10.2991/icille-18.2019.58. 
function of swear words in a non-English language film and Kristiano and $\mathrm{Ardi}^{21}$ who examined swear words in an English film. Other studies focused on the practice of teaching swearing in foreign language learning have been executed by Andang \& Bram, ${ }^{22}$ Finn, ${ }^{23}$ and Horan, ${ }^{24}$ and the comparison of English swear words utilization in different countries as studied by Goddard, ${ }^{25}$ and the variety of English taboo words in a non-native English speaking country as Gao's research. ${ }^{26}$ All of the previous research explore the variety, function, comparison, and utilization of swear words. The current research continues offering a deeper understanding of the topic by addressing the semantic referents of swear words and swearing motives.

As the representation of everyday life, films become the devices for the transmission of swearing. This signals that the role of swear words as taboo and offensive expressions alert to be less

\footnotetext{
${ }^{21}$ Kristiano and Ardi, "Swear Words in Bad Boys II: A Semantic Analysis," 191.

22 Kristina Andang and Barli Bram, "Swear Words and Their Implications for English Language Learning-Teaching," LLT Journal: A Journal on Language and Language Teaching 21 (2018): 4349, https://doi.org/10.24071//lt.2018.Suppl2105.

${ }^{23}$ Eileen Finn, "Swearing: The Good, the Bad \& the Ugly," ORTESOL Journal 34 (2017): 17.

${ }^{24}$ Horan, "You Taught Me Language; and My Profit on't/ls, I Know How to Curse': Cursing and Swearing in Foreign Language Learning," 283.

${ }^{25}$ Cliff Goddard, "'Swear Words' and 'Curse Words' in Australian (and American) English. at the Crossroads of Pragmatics, Semantics and Sociolinguistics," Intercultural Pragmatics 12, no. 2 (2015): 1, https://doi.org/10.1515/ip-2015-0010.

26 Chunming Gao, "A Sociolinguistic Study of English Taboo Language," Theory and Practice in Language Studies 3, no. 12 (2013): 2310-14, https://doi.org/10.4304/tpls.3.12.2310-2314.
}

taboo and more acceptable across societies. Once Upon a Time... in Hollywood released in 2019 is a drama, comedy film about a TV star Rick Dalton, Leonardo DiCaprio, and his longtime stunt double Cliff Booth, Brad Pitt, who are struggling to achieve their career again in the film industry in 1969 Los Angeles. The film becomes the focus of the present study as it contains severe profanity, is relatively new, and is accessible.

Since the phenomenon of swear words in films has gone largely unanswered, the present study seeks to investigate the semantic referents in an that film. Moreover, swearing motives need to be studied to ensure that people acknowledge the cause of swearing. Because of becoming a part of communication, people should understand the use of swear words be wise in their conversations. To fulfill these aims, this research study about the semantic referents of swear words in the Once Upon a Time... in Hollywood film, and also what are the motives of swearing in the Once Upon a Time... in Hollywood film.

\section{B. Method}

This qualitative research analyzed selected dialogues containing swear words in the Once Upon a Time... in Hollywood film to investigate the semantic referents and the motives of swearing. The approach adopted in this research was content analysis as it can cover written and visual data to be identified. ${ }^{27}$

\footnotetext{
27 Donald Ary et al., Introduction to Research in Education, 10th ed. (Boston: Cengage Learning, 2018), 457.
} 
The film was downloaded from https://yts.mx. ${ }^{28}$ Furthermore, the script of the film was taken from https://isubtitles.org. ${ }^{29}$

The data were collected by several steps, which were realized through watching and taking-note techniques. To avoid providing double data, one sample was used as the representation of the same sentences whose semantic referents and motives of swearing were identical.

To discover the semantic referents, the script was analyzed based on the categorization of semantic referents proposed by Jay. ${ }^{30}$ To support the theory and check the meanings of the swear words, some dictionaries and an encyclopedia were used, which included Longman Dictionary, Merriam-Webster Dictionary, Encyclopedia of Swearing, and www. urbandictionary.com. Meanwhile, the motives of swearing theory proposed by Anderson (as cited in Karjalainen) was used as the basis for examining the characters' reasons for swearing. ${ }^{31}$

${ }^{28}$ Quentin Tarantino, Once Upon a Time... In Hollywood, Comedy-Drama (Sony Picture Releasing, 2019), https://yts.mx/movie/once-upona-time-in-hollywood-2019.

29 "Once Upon a Time ... in Hollywood - 2019 . English Subtitles," isubtitles.info, accessed October 21, 2020, https://isubtitles.org/once-upon-a-time-inhollywood/english-subtitles/1548808.

${ }^{30}$ Jay, "The Utility and Ubiquity of Taboo Words," 154.

${ }^{31}$ Anderson in Markus Karjalainen, "Where Have All the Swearwords Gone? An Analysis of the Loss of Swearwords in Two Swedish Translations of $\mathrm{J}$. D. Salinger's Catcher in the Rye" (Thesis, University of Helsinki, 2002), 24-26,

\section{Results}

\section{Types of Semantic Referents of Swear Words in Once Upon a Time... in Hollywood}

The semantic referents of swear words in Once Upon a Time... in Hollywood were analyzed based on Jay's theory. ${ }^{32}$ The following table displays the distribution of each category of the semantic referent.

Table 1.

Types of semantic referents of swear words in Once Upon a Time... in Hollywood

\begin{tabular}{|c|c|c|c|}
\hline No. & $\begin{array}{l}\text { Types of } \\
\text { Semantic } \\
\text { Referents of } \\
\text { Swear Words }\end{array}$ & Quantity & $\begin{array}{l}\text { Percentage } \\
(\%)\end{array}$ \\
\hline 1. & $\begin{array}{l}\text { Offensive } \\
\text { Slang }\end{array}$ & 10 & 17 \\
\hline 2. & $\begin{array}{l}\text { Profane or } \\
\text { Blasphemous }\end{array}$ & 9 & 15 \\
\hline 3. & $\begin{array}{l}\text { Psychological- } \\
\text { Physical-Social } \\
\text { Deviations }\end{array}$ & 9 & 15 \\
\hline 4. & $\begin{array}{l}\text { Scatological } \\
\text { and Disgusting } \\
\text { Objects }\end{array}$ & 9 & 15 \\
\hline 5. & $\begin{array}{l}\text { Sexual } \\
\text { References }\end{array}$ & 7 & 12 \\
\hline 6. & $\begin{array}{l}\text { Substandard } \\
\text { Vulgar Terms }\end{array}$ & 6 & 10 \\
\hline 7. & $\begin{array}{l}\text { Ethnic-Racial- } \\
\text { Gender Slurs }\end{array}$ & 4 & 7 \\
\hline 8. & Animal Names & 3 & 5 \\
\hline 9. & $\begin{array}{l}\text { Ancestral } \\
\text { Allusions }\end{array}$ & 2 & 4 \\
\hline Total & & 59 & 100 \\
\hline
\end{tabular}

As many as 59 semantic referents of swear words (table 1) were identified on the whole, in which offensive slang (17\%) became the most prevailing referent and

32 Jay, "The Utility and Ubiquity of Taboo Words," 154. 
were followed by profane and blasphemous (15\%), psychologicalphysical-social deviations (15\%), scatological and disgusting objects (15\%), sexual references (12\%), substandard vulgar terms (10\%), ethnic-racial-gender slurs $(7 \%)$, animal names $(5 \%)$, and ancestral allusions (4\%).

\section{a. Offensive Slang}

The form of slang shifts from time to time. Modern slang involves some words containing similarity and familiarity with particular activities and showing the creativity of inventing the new term. ${ }^{33}$ Joker, numbnut, prick, jughead, bullshit, shithole, sick mind, crap, phony, and poontang were the offensive slangs uttered in the Once Upon a Time... in Hollywood film.

Some slangs are produced as a new name for something, such as sick mind which refers to a deranged psychological state and phony which means an impostor or a fake. The word poontang is related to a sexual act. Slang is used to identify a person with a particular characteristic, such as the words jokers and prick, which means annoying and obnoxious people along with numbnut and jughead which denote stupid persons. Slang also functions to denote something unpleasant, such as bullshit which means nonsense, shithole which denotes a disgusting place, and crap which means excrement.

${ }^{33}$ Edwin L. Battistella, Bad Language: Are Some Words Betters than Others? (New York: Oxford University Press, 2007), 84-85.

\section{b. Profane and Blasphemous}

There were nine swear words categorized as profane referents and were represented by goddamn, damn, God, gosh, Jesus, Jesus Christ, hell, heck, and devil. All of these phrases were profanity instead of insults to a particular belief or religion. Jesus and Jesus Christ are specific terms related to Christianity, while God, devil, and hell are common terms for some religions or beliefs. The words goddamn and damn are used to condemn to fate or for some real fault. Gosh and heck are the euphemism of the words God and hell. Jay and Janschewitz suggest that euphemism is a linguistic choice that replaces any unpleasant and inappropriate words to be more polite and less offensive. ${ }^{34}$ These euphemisms were uttered to avoid using the initial swear words since the characters wanted to lessen the inappropriateness of using God, which is believed to have power over nature, and hell, a place believed as the home of wicked people, as swear words.

\section{c. Psychological - Physical - Social Deviations}

There were seven swear words counted as psychological-physical-social deviations, consisting of stupid, idiot, weirdo, jackass, creepy, dirty, shaggy, loser, and drunk. The words stupid, idiot, weirdo, and jackass denote the psychological state, which is the low intelligence level. Meanwhile, physical

34 Timothy Jay and Kristin Janschewitz, "The Pragmatics of Swearing," Journal of Politeness Research 4, no. 2 (2008): 267-88, https://doi.org/10.1515/jplr.2008.013. 
appearance consists of physical attractiveness, such as creepy, dirty, and shaggy. Drunk and loser are included under social deviation since drunk represents amoral behavior, and a loser illustrates a failing and incompetent person to succeed.

\section{d. Scatological and Disgusting Objects}

Scatological and disgusting objects were realized in nine words, namely, asshole, butt, junk, carcass, shit, horseshit, piece of shit, and shittiest, and distributed in 52 utterances in the film. The words ass, butt, and asshole are parts of excretion organs, while the terms shit, crap, and horseshit are excretion products. Junk and carcass are considered disgusting objects since junk denotes trash, and carcass means the remnants of a dead animal.

\section{e. Sexual References}

It was found 120 sexual references consisted of sexual acts, sexual organs, and sexual deviations. In terms of sexual acts, it only has the variations of the word fuck, such as fuck, fucking, fucker, and fucked. The variations were applied 113 times, with the word fucking became the one uttered more frequently. This could illustrate that the term fucking is more flexible and likely to be the most popular interjection. As sexual anatomies, the terms dick and cock, which refer to male genitals, were uttered in the dialogue by male characters. The sexual deviation only includes the word motherfucker, which occurred with the different forms of singularity and plurality.

\section{f. Substandard Vulgar Terms}

Substandard vulgar terms were represented by horse's ass, shit-scared, holy shit, pig-shit, shit-fuck, and piss-fart. The prefixes shit- were added in shitscared and shit-fuck while pig-shit contained suffixes -shit. These terms are considered vulgar since they are related to sexual acts, body parts, and body products. Holy shit and piss-fart are word constructions that are below the English standard. Moreover, all these vulgar terms are not considered grammatically correct.

\section{g. Ethnic - Racial - Gender Slurs}

White, redhead, ginger-haired, and beaner were served as ethnic-racialgender slurs in the film. In terms of swear words, white refers to a person whose skin color is white. The phrases redhead and ginger-head denote the same meaning, that is a person, mostly a woman whose hair is a color between red, brown, and orange. In other words, this person has reddish hair. Beaner is an offensive word referring to a Mexican or Mexican descent.

\section{h. Animal Names}

Seven utterances containing animal names were produced in Once Upon a Time... in Hollywood film. The referents were presented by bitch, baboon, and pig. The word bitch refers to a female dog and baboon is one of the 23 genera of Old World monkeys. The characters uttered some animal names, but not as swear words since they didn't contain any offensive meaning. The words pussy and snake were used as proper nouns as they 
referred to the characters' names. A word construction containing animal name is also used as an appropriate slang. The term owl-hoot is a slang which denotes a cowboy of the old American West.

\section{i. Ancestral Allusions}

There were two phrases categorized in this type of referent, consisting of bastard and son of a bitch. The term bastard denotes an illegitimate child. Son of a bitch is used to illustrate the relationship between a male and his mother. However, because of the nonselective use over the centuries, the term lost its effect and is generalized now. ${ }^{35}$ This kind of swear word was only uttered by male characters and applied to both persons and circumstances.

\section{The Motives of Swearing in the Once Upon a Time... in Hollywood}

The distribution of motives of swearing in Once Upon a Time... in Hollywood film were presented in table 2 below.

Table 2.

Motives of swearing in Once Upon a Time... in Hollywood film

\begin{tabular}{llll}
\hline $\begin{array}{l}\text { No. } \\
\text { Motives of } \\
\text { Swearing }\end{array}$ & Quantity & $\begin{array}{l}\text { Percentage } \\
(\%)\end{array}$ \\
\hline 1. Psychological & 96 & 41 \\
2. Social & 82 & 35 \\
3. Linguistic & 56 & 24 \\
\hline \multicolumn{2}{l}{ Total } & 234 & 100 \\
\hline
\end{tabular}

${ }^{35}$ Geoffrey Hughes, An Encyclopedia of Swearing: The Social History of Oaths, Profanity, Foul Language, and Ethnic Slurs in the EnglishSpeaking World (New York: Routledge, 2015), 441. https://doi.org/10.4324/9781315706412.
All in all, 234 utterances containing 275 swear words were identified, out of which psychological was the most frequent motive with 96 occurrences (Table 2). On the contrary, linguistic motives were realized with the lowest frequency, only with 56 utterances. As for social motives, it was the second most prevailing type with 82 utterances.

\section{a. Psychological Motives (PM)}

Psychological motives which deals with someone's either positive or negative emotions, are presented through data (1) and (2). Based on this theory, son of a bitch, the fuck, and fucking bitch are uttered as an expression of feelings and attitudes in (1) and (2), respectively.

Cliff Booth : Here. Put these on. Don't cry in front of the Mexicans.

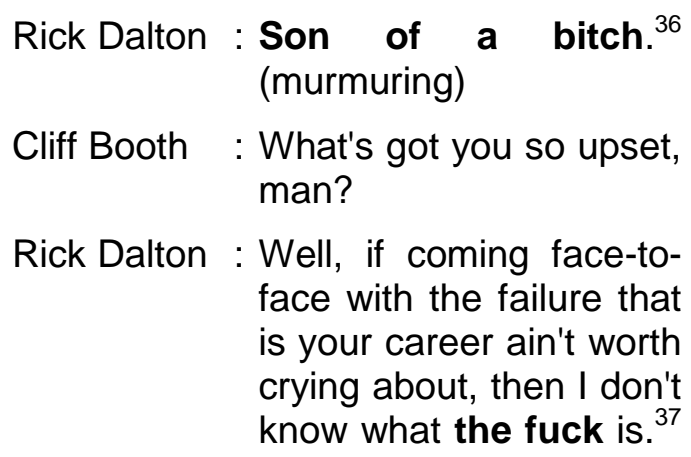
(1)

In data (1), the swearing words of son of a bitch and the fuck are used by Rick Dalton to show the feeling of upset. Dalton thinks that his career and fame in the film industry are no longer shining as what he used to be since he is suggested to do an Italian-genre movie, which he feels is beneath him.

\footnotetext{
${ }^{36}$ Isubtitles.org, "Once Upon a Time... in Hollywood (2019) English Subtitles," 2019.

37 Isubtitles.org.
} 
Tex Watson : I locked the car. You'll need keys to get in.

Flowerchild : Oh. Right. Thank you. Okay. l'Il be right back.

Tex Watson : Okay. Just hurry up.

Flowerchild : Yeah, just a little minute. (car door shuts), (engine starts), (tires squealing)

Sadie

: Oh, that fucking
bitch! $!^{38}(2)$

Datum (2) is uttered by Sadie to show her anger and disbelief towards Flowerchild who runs away and leaves them there to continue killing Rick Dalton without her. All of them belong to the same cult, hence Sadie doesn't think that Flowerchild will betray them.

Based on the analysis, psychological motives exist since the swearing expressions are uttered purely because of psychological impulsion. Regardless of any other motives, psychological motives include the urge of emotive feelings, such as anger, shock, surprise, frustration, and upset without any disturbance of other motives.

\section{b. Social Motives (SM)}

Social motives, which focus on friendliness, social intimacy, or even social distance, are presented in data (3) and (4).
Rick Dalton : I don't need you. Not today. Go home, fix my antenna, do whatever. See you at wrap.

Cliff Booth : Hey! You're Rick fucking Dalton. Don't you forget it. ${ }^{39}(3)$
In datum (3), fucking functions as a filler in Ric Dalton's full name. Cliff Booth uses the swear word to remind Rick Dalton that he is still the best actor even tough he is starring in a pilot. This swear word signifies the friendliness and social intimacy between Dalton and Booth.
Rick Dalton : You fucking hippies came up here to smoke dope on a dark road, huh? Next time you want to try that, fix your fucking muffler. ${ }^{40}$

Tex Watson : Look, we're really sorry we disturbed you. (4)

In data (4), fucking hippies is uttered by Dalton to insult Tex Watson and his friends because of their looks which are closely related to hippie culture, which can be noticed by their long messy hairstyles and hippie outfits. Moreover, to humiliate Watson and his friends, Dalton accuses them of smoking dope as hippies appear to consume weed as a part of their movement. The phrase fucking muffler is used to both mock Watson's defective car and rudely remind him that his car is not in a good condition, hence it needs some reparation. The utterances in data (4) show the social distance between Rick Dalton and Tex Watson and his friends.

\section{c. Linguistic Motives (LM)}

Linguistic motives of swearing happen when the swear words are used to emphasize on what the characters attempt to communicate and the topic under discussion.

\footnotetext{
${ }^{38}$ Isubtitles.org.

${ }^{39}$ Isubtitles.org.
}

${ }^{40}$ Isubtitles.org.

OKARA: Jurnal Bahasa dan Sastra, Vol. 14, No. 2, November 2020 
Rick Dalton : No. He wants to help me get into Italian movies.

Cliff Booth : Then what's the problem?

Rick Dalton : I gotta do fucking Italian goddamn movies! That's the fucking problem! $!^{41}(5)$

Data (5) go along with the claim that linguistic motives merely give an emphasis. Rick Dalton is enhancing that he refuses to do an Italian film and avoids feeling like a has-been by saying fucking Italian goddamn movies and the fucking problem.

$\begin{array}{ll}\text { Janet } & \begin{array}{l}\text { : Oh, my God! What the } \\ \text { fuck did you do to my } \\ \text { car? } !^{42}\end{array} \\ \text { Randy } & \begin{array}{l}: \text { What the fuck did you } \\ \text { do to her car? } ?^{43}\end{array} \\ \text { Cliff Booth } \quad \begin{array}{l}: \text { I threw this little prick } \\ \text { into it, but I did not know } \\ \text { it was her car. (6) }\end{array}\end{array}$

For instance, in data (6), the fuck is uttered twice by two different characters, and each phrase reveals a different motive. The first phrase focuses on showing the feeling of shock while the second one is used to emphasize the reason why Bruce Lee and Cliff Booth make Janet's car dent. The samples clarify that each swear word has a different motive based on its context.

The present study's findings demonstrate that a wide variety of swear words exist in Once Upon a Time... in Hollywood film. Moreover, all of the semantic referents are carried in the swear words but not allocated equally. This supports the viewpoint held by Kristiano and Ardi who see the semantic referents as one unity of swear words ranged based on its offensiveness. ${ }^{44}$ Likewise, Cahyani and Setiawan argue that the forms of swear words in a nonEnglish language film also include sexual reference, animal names, body parts, and psychological conditions and all of them are not equally distributed in the film. ${ }^{45}$ This finding is also in line with Andang and Bram regarding swear words' construction as the influence of their occurrences. ${ }^{46}$

The highest frequency of semantic referents is offensive slang. The finding contradicts Kristiano and Ardi's research, which reveals that the most prevailing semantic referent of swear words is profanity. ${ }^{47}$ The higher rate of slang might be primarily due to the nature of creating new terms to ease communication. This substantiates Battistella's suggestion that slang invents new words to show the inventiveness of language. ${ }^{48}$ However, slangs were considered the lowest form of communication since some were constructed out of poor word choices. Instead, because of the rich and insightful

\footnotetext{
${ }^{44}$ Kristiano and Ardi, "Swear Words in Bad Boys II: A Semantic Analysis," 197.

45 Cahyani and Setiawan, "Swearing Words on Yowis Ben Movie by Fajar Nugros and Bayu Skak," 285-87.

46 Andang and Bram, "Swear Words and Their Implications for English Language LearningTeaching," 46.

47 Kristiano and Ardi, "Swear Words in Bad Boys II: A Semantic Analysis," 194.

48 Battistella, Bad Language: Are Some Words Betters than Others?, 84-85.
} 
variation, slang becomes part of standard language and continuously emerges. Although some slang words are offensive, they are still popular among people nowadays.

It is also acknowledged that psychological is the most dominant motive of swearing. The reason why this is the case might be due to the function of swearing itself that is to represent the speaker's feelings. In line with this, as the film is going to reach the climax, swear words become more frequent. This happens because the series of conflicts leading to the climax start rising and the tension between the characters turns to be more heated, causing them to express their emotions and attitude through swear words. The present study provides further support for Stephens and Zile's proposition that raising emotional arousal can cause and facilitate swearing as the expression of powerful emotion. ${ }^{49}$

The similarity this study bears to Finn's study is that both show the positive function of swearing. ${ }^{50}$ In her study, swearing indicates closeness, intimacy, acceptance, and inclusiveness between speakers. Horan explains that while swear words carry strong and creative emotional language, their function is contextdependent and is determined by the formality and the intensity of a specific emotional experience. ${ }^{51}$ In line with this,

49 Stephens and Zile, "Does Emotional Arousal Influence Swearing Fluency?," 993.

${ }^{50}$ Finn, "Swearing: The Good, the Bad \& the Ugly," 22-23.

${ }^{51}$ Horan, "'You Taught Me Language; and My Profit on't/ls, I Know How to Curse': Cursing and Swearing in Foreign Language Learning," 295.
Gao reveals that the level of offensiveness in swear words can be lessened by euphemism. ${ }^{52}$

The study's findings are in compliance with Goddard's suggestion, considering swear words as individual expressions carrying particular meaning and are bound to the context. ${ }^{53}$ The current paper indicates that swear words are powerful linguistic choices signifying freedom as people are no longer reluctant to include them in daily conversations regardless of the offensiveness and the negative consequences. It is also well understood that swear words mostly occur directly in informal encounters because of professional language expectations, norms, and behaviors in formal settings. This claim upholds Baruch's viewpoint, et al., whom regard swear words as expressions of emotional release that happen mostly in informal settings. ${ }^{54}$

The least part of values and belief in society is reflected via swear words. Nevertheless, the application of them manifests strength for the addressers. Because of its powerful motion, swear words come up with stress relief through verbal aggression instead of physical ones. The empirical argument above complies with the claim of Popuşoi, Havârneanu, and Havârneanu' that swear words are the expressions of verbal

\footnotetext{
52 Gao, "A Sociolinguistic Study of English Taboo Language," 2313.

53 Goddard, "'Swear Words' and 'Curse Words' in Australian (and American) English. at the Crossroads of Pragmatics, Semantics, and Sociolinguistics," 212.

54 Yehuda Baruch et al., "Swearing at Work: The Mixed Outcomes of Profanity," 158.
} 
aggression that lower physical aggression and self-reported negative affective valence. ${ }^{55}$

Given the prominent status of swear words in communication, these findings offer implications for general readers, suggesting that they should be wise in expressing their feelings because swear words are powerful linguistic choices containing a different degree of offensiveness. Moreover, because of the mutual relation between swear words and social life, the utilization of swear words might need to be included in the curriculum of education. There are also implications for more profound research about related issues to give a deeper understanding and enrich the knowledge about swear words. Future studies may examine the relation between non-English language films and the occurrence of semantic referents and motives of swearing as well as the effect of race and gender in the occurrence of swearing.

\section{Conclusion}

Based on the analysis of semantics referents of swear words in Once Upon a Time... in Hollywood movie, 59 semantic referents are found and divided into nine notions, such as offensive slang (17\%), profane or blasphemous (15\%), psychologicalphysical-social deviations (15\%), scatological and disgusting objects (15\%), sexual references (12\%), substandard vulgar terms (10\%), ethnic-racial-gender

\footnotetext{
${ }^{55}$ Popuşoi, Havârneanu, and Havârneanu, "'Get the F\#*k out of My Way!' Exploring the Cathartic Effect of Swear Words in Coping with Driving Anger," 224.
}

slurs $(7 \%)$, animal names (5\%), and ancestral allusions (4\%). Because of the urge to create new terms to ease communication, offensive slang becomes the most dominant semantic referent with 10 referents. Three reasons contributing to the reasons for swearing are coded as psychological motives, social motives, and linguistic motives. The most prevailing motive is psychological, as it indicates the characters' emotions. General readers are expected to improve their knowledge about English swear words and maintain their politeness while communicating.

\section{References}

Andang, Kristina, and Barli Bram. "Swear Words and Their Implications for English Language LearningTeaching." LLT Journal: A Journal on Language and Language Teaching 21 (2018): 43-49. https://doi.org/10.24071/llt.2018.Sup pl2105.

Andersson, L., and P. Trudgill. Bad Language. Oxford: Blackwell, 1990.

Ary, Donald, Lucy Cheser Jacobs, Christine K. Sorensen Irvine, and David Walker. Introduction to Research in Education. 10th ed. Boston: Cengage Learning, 2018.

Baruch, Yehuda, Rea Prouska, Ariane Ollier-Malaterre, and Jennifer Bunk. "Swearing at Work: The Mixed Outcomes of Profanity." Journal of Managerial Psychology 32, no. 2 (2017): 149-62. https://doi.org/10.1108/JMP-042016-0102.

Battistella, Edwin L. Bad Language: Are Some Words Better than Others? New York: Oxford University Press, 2007. https://doi.org/10.1093/acprof:oso/9 780195172485.001.0001. 
Cahyani, Putri Dwi, and Teguh Setiawan. "Swearing Words on Yowis Ben Movie by Fajar Nugros and Bayu Skak." In International Conference on Interdisciplinary Language, Literature and Education (ICILLE 2018), 282-87. Paris: Atlantis Press, 2019. https://doi.org/10.2991/icille18.2019.58.

Finn, Eileen. "Swearing: The Good, the Bad \& the Ugly." ORTESOL Journal 34 (2017): 17-26.

Gao, Chunming. "A Sociolinguistic Study of English Taboo Language." Theory and Practice in Language Studies 3, no. 12 (2013): 2310-14. https://doi.org/10.4304/tpls.3.12.231 0-2314.

Goddard, Cliff. "'Swear Words' and 'Curse Words' in Australian (and American) English. at the Crossroads of Pragmatics, Semantics and Sociolinguistics." Intercultural Pragmatics 12, no. 2 (2015): 189218. https:/doi.org/10.1515/ip-20150010.

Holgate, Eric, Isabel Cachola, Daniel Preotiuc-Pietro, and Junyi Jessy Li. "Why Swear? Analyzing and Inferring the Intentions of Vulgar Expressions." In Proceedings of the 2018 Conference on Empirical Methods in Natural Language Processing, EMNLP 2018, 4405-14. Brussels, 2018. https://doi.org/10.18653/v1/d181471.

Holmes, Janet. An Introduction to Sociolinguistics. 4th ed. New York: Routledge, 2013. https://doi.org/10.1525/jlin.2003.13.2 .252 .

Horan, Geraldine. "'You Taught Me Language; and My Profit on't/ls, I Know How to Curse': Cursing and Swearing in Foreign Language Learning." Language and Intercultural Communication 13, no. 3 (2013): 283-97. https://doi.org/10.1080/14708477.20 13.804533.
Hughes, Geoffrey. An Encyclopedia of Swearing: The Social History of Oaths, Profanity, Foul Language, and Ethnic Slurs in the EnglishSpeaking World. New York: Routledge, 2015. https://doi.org/10.4324/9781315706 412.

isubtitles.info. "Once Upon a Time ... in Hollywood - 2019 - English Subtitles." Accessed October 21, $2020 . \quad$ https://isubtitles.org/onceupon-a-time-in-hollywood/englishsubtitles/1548808.

Jay, Timothy. "The Utility and Ubiquity of Taboo Words." Perspectives on Psychological Science 4, no. 2 (2009): 153-61. https://doi.org/10.1111/j.17456924.2009.01115.x.

Jay, Timothy. Why We Curse: A NeuroPsycho-Social Theory of Speech. Amsterdam: John Benjamins, 1999. https://doi.org/10.1075/z.91.

Jay, Timothy, and Kristin Janschewitz. "The Pragmatics of Swearing." Journal of Politeness Research 4, no. 2 (2008): 267-88. https://doi.org/10.1515/jplr.2008.013.

Karjalainen, Markus. "Where Have All the Swearwords Gone? An Analysis of the Loss of Swearwords in Two Swedish Translations of J. D. Salinger's Catcher in the Rye." Thesis, University of Helsinki, 2002.

Kreidler, Charles W. Introducing English Semantics. London: Routledge, 1998. https://doi.org/10.4324/9780203265 574.

Kristiano, Johan Tobias, and Priyatno Ardi. "Swear Words in Bad Boys II: A Semantic Analysis." Journal: A Journal on Language and Language Teaching 21, no. 2 (2018): 191-98. https://doi.org/10.24071/llt.2018.210 208. 
Philipp, Michael C., and Laura Lombardo. "Hurt Feelings and Four Letter Words: Swearing Alleviates the Pain of Social Distress." European Journal of Social Psychology 47, no. 4 (2017): 517-23. https://doi.org/10.1002/ejsp.2264.

Popuşoi, Simona A., Grigore M. Havârneanu, and Corneliu E. Havârneanu. "Get the F\#*k out of My Way!' Exploring the Cathartic Effect of Swear Words in Coping with Driving Anger." Transportation Research Part F: Traffic Psychology and Behaviour 56 (2018): 215-26. https://doi.org/10.1016/j.trf.2018.04. 013.

Stapleton, Karyn. "Swearing." In Interpersonal Pragmatics, 289-305. New York: De Gruyter Mouton, 2010.

https://doi.org/10.1515/9783110214 338.2.289.

Stephens, Richard, and Amy Zile. "Does Emotional Arousal Influence Swearing Fluency?" Journal of Psycholinguistic Research 46, no. 4 (2017): 983-95. https://doi.org/10.1007/s10936-0169473-8.

Tarantino, Quentin. Once Upon a Time... In Hollywood. Comedy-Drama. Sony Picture Releasing, 2019. https://yts.mx/movie/once-upon-atime-in-hollywood-2019.

Trudgill, Peter. Sociolinguistics: An Introduction to Language and Society. 4th ed. London: Penguin Books, 2000. https://doi.org/10.2307/326846.

Vingerhoets, A. J. J. M., Lauren M. Bylsma, and Cornelis de Vlam. "Swearing: A Biopsychosocial Perspective." Psychological Topics 22, no. 2 (2013): 287-304. 